\title{
Detection of Lsr2 Gene of Mycobacterium leprae in Nasal Mucus
}

\author{
Luiz Antonio Custodio ${ }^{1 *}$, Alexandre Saito ${ }^{2}$, Marla Karine Amarante ${ }^{1}$, Thiago Cezar \\ Fujita $^{2}$, Aparecida de Lourdes Perim ${ }^{1}$, Ivete Conchon Costa ${ }^{2}$, Ionice Felipe ${ }^{2}$ and Shiduca \\ Itow Jankevicius ${ }^{2}$ \\ ${ }^{I}$ Departamento de Patologia Aplicada, Análise Clínicas e Toxicológicas; Centro de Ciências da Saúde; \\ Universidade Estadual de Londrina - PR - Brasil. ${ }^{2}$ Departamento de Patologia Geral; Centro de Ciências \\ Biológicas; Universidade Estadual de Londrina; Rodvia Celso Garcia Cid, 86051-990; Londrina - PR - Brasil
}

\begin{abstract}
In the present study, nasal mucus from patients with leprosy were analyzed by PCR using specific primers for Lsr2 gene of Mycobacterium leprae. The presence of Lsr2 gene in the nasal mucus was detected in $25.80 \%$ of patients with paucibacillari leprosy, and $23.07 \%$ of contacts. Despite the absence of clinical features in the contact individuals, it was possible to detect the presence of Lsr2 gene in the nasal mucus of these individuals. Therefore, PCR detection of M. leprae targeting Lsr2 gene using nasal mucus samples could contribute to early diagnosis of leprosy.
\end{abstract}

Key words: Mycobacterium leprae, leprosy, hanseniase, nasal mucus, PCR.

\section{INTRODUCTION}

Although a long time has elapsed since the discovery of Mycobacterium leprae by Gerhard Armauer Hansen in 1873 (De Zubiria et al. 2003; Fernandes et al. 2004), the understanding of the biology of this microorganism is still incomplete. For instance, the reasons for the inability of $M$. leprae to grow in media and conditions commonly used for bacteria is still not known. Recent studies have presented interesting data about the relationship between $M$. leprae and its host (Zanazzi et al. 2000; Nurse 2003), but many relevant questions about it remain unanswered (Siddiqui et al. 2003). An important aspect of mycobacterial pathogenesis is the ability of the pathogen to establish long lasting latent infections in the host. Leprosy (or Hanses's Disease) is a millenary chronic infectious granulomatous disease, which attacks skin, peripheral nerves and mucous membranes and is associated with immune response and secondary infections involving the status from the host. The World Health Organization estimates that more than 12 million people are affected by leprosy in the world (Braga 2002). Leprosy remains highly endemic in several countries such as Angola, Brazil, Central African Republic, Democratic Republic of Congo, India, Madagascar, Mozambique, Nepal, and the United Republic of Tanzania. It has been a problem in the countries which received a large number of immigrants from the endemic areas (Chae et al. 2002; Jianping et al. 2004). (Wiwanitkit 2005) performed a database search in order to find the genes of $M$. leprae recorded with complete sequences and compared their homology

\footnotetext{
* Author for correspondence: harpialc@hotmail.com
} 
to human genomes using BLAST method. It is known that B cell responses to specific sequences within the Lsr antigen have been shown to be associated with the immunopathological responses in leprosy patients with erythema nodosum leprosum. It has been observed that some B and T cell epitopes localized to the regions with amino acid substitutions may account for the putative differential responsiveness to this antigen in tuberculosis and leprosy (Oftung et al. 2000). (Misra et al. 1995) found that the patients who did not show acid-fast bacilli in the tissues by the conventional methods presented positive for $M$. leprae DNA. PCR was initially used for the detection this pathogen in 1989 (Hartskeerl et al. 1989; Woods et al. 1989) and since them it has been used in most different clinical specimens as skin (De Wit et al. 1991; Yoon et al. 1993), nasal swab and hair bulb (Santos et al. 1995) and oral swab (Goulart et al. 2001). A proteomic approach was undertaken to identify the proteins present in the soluble/cytosol and membrane subcellular fractions obtained from the armadillo derived from M. leprae. Proteins from each fraction were separated by two-dimensional gel electrophoresis (2-DE) and identified by mass spectrometry. A total of 147 protein spots were identified from 2DE patterns and shown to comprise the products of 44 different genes, 28 of them corresponding to new proteins (Marques et al. 2004).

Multidrug treatment has contributed to disease control, but new cases are being reported, showing that the development of early detection methods is imperative. Knowledge of the genomic sequence of M. leprae (Cole et al. 2001) is an important step for understanding this bacterium and its interactions with its host, as well as for developing the detection tests such as those based on PCR (Meima et al. 2004) or helicase-dependent amplification (HDA) (Young 2001; Vincente et al. 2004). Several PCR-based methods for the detection and evaluation of leprosy have been reported (Zanazzi et al. 2000; Santos et al. 2001; Guerrero et al. 2002; Torres et al. 2003; Sakamuri et al. 2009). The aim of this work was to evaluate the PCR detection of lsr2 gene of M. leprae in nasal mucus.

\section{MATERIAL AND METHODS}

With the approval at the Human Ethics Committee of Londrina State University and Philantropic Society Humanitas, Parana, Brazil, 130 Brazilian patients were included in thisn study. DNA sequences of $M$. leprae were analyzed by BLAST (http://ncbi.nlm.nih.gov/BLAST) and the rate of repetition in the genome was checked searching for a unique sequence copy, as well as for similarity with the genome of other microorganisms. Lsr2 gene was analyzed in the PRIMER3 program (http://frodo.wi.mit.edu/ primer3/) to draw the primers and these were analyzed by the BLAST program, checking its specificity to $M$. leprae. The 130 patients enrolled in this study were grouped as following: 22 samples $(\sim 16,9 \%)$ from multibacillary leprosy, 31 samples $(\sim 23,8 \%)$ from paucibacillari leprosy, 52 samples (40\%) from asymptomatic household contacts of patients with leprosy and 25 samples $(\sim 19,2 \%)$ from people without history of contact with leprosy. Mycobacterium fortuitum (11 isolates), Mycobacterium scrofulaceum (1 isolate), Mycobacterium tuberculosis (29 isolates), Mycobacterium avium (4 isolates), which were kindly provided by Dra. Halha Ostrensky Saridakis, (Centro de Ciências Biológicas, Departamento de Microbiologia - Universidade Estadual de Londrina - Brasil), were used as controls.

Swab samples of nasal mucus were collected using sterile cotton swabs wet in phosphate buffer $(\mathrm{pH}$ 7.0), maintained at $4^{\circ} \mathrm{C}$ until transferred to Eppendorf ${ }^{\circledR}$ tubes containing $1.0 \mathrm{~mL}$ of ultra pure water and stored at $-20^{\circ} \mathrm{C}$ until DNA extraction.

\section{DNA extraction}

Genomic DNA was isolated following the method proposed by (Torres et al. 2003) with modification. Briefly, $200 \mu \mathrm{L}$ of the sample was centrifuged 15 minutes at $12.000 \mathrm{~g}$ and the pellet was treated at $100^{\circ} \mathrm{C}$ for 1 minute and freezing in nitrogen for 3 minutes. It was resuspended in $100 \mu \mathrm{l}$ of Tris- $\mathrm{HCl} 50 \mathrm{mM}$ buffer (pH 8.0), containing lysozime $10 \mathrm{mg} / \mathrm{mL}$, incubated at $37^{\circ} \mathrm{C}$ for 30 minutes, added $10 \mu \mathrm{L}$ of proteinase $\mathrm{K} 50$ $\mathrm{mg} / \mathrm{mL}$, followed by the addition of $1.0 \mu \mathrm{l}$ of Triton X-100 (10\%). The mixture was kept at $55^{\circ} \mathrm{C}$ for two hours and after the addition of absolute ethanol centrifuged at $10.000 \mathrm{~g}$ for five minutes. The DNA was suspended in ultra pure water and stored at $-20^{\circ} \mathrm{C}$ until use.

\section{Amplification conditions}


PCR products were analyzed by the electrophoresis on acrylamide gel (10\%) and detected by a nonradioisotopic technique using a commercially available silver staining method (data not shown).

\section{RESULTS AND DISCUSSION}

The Lsr2 gene of M. leprae codifies a protein of $15 \mathrm{kDa}$ with capability of stimulating $\mathrm{T}$ lymphocytes. Table 1 shows the results of amplifications by PCR from 130 samples of nasal mucus of leprosy patients, asymptomatic household contacts of patients with leprosy and people without contact history. Samples with negative PCR results were tested for the presence of inhibitors in the reaction, by adding standardized DNA to the extracted sample. To test the specificity of PCR-probing with the primers for M. leprae Lsr2 region to Lsr2, the gene of other mycobacterias as M. avium, M. fortuitum, $M$. scrofulaceum and $M$. tuberculosis were tested in the same region. In this context, all the strains were negative in PCR test.

Table 1 - Detection of Lsr2 gene of M. leprae in smear of nasal mucus from patients.

\begin{tabular}{lccc}
\hline \multirow{2}{*}{ Class } & \multicolumn{2}{c}{ PCR-probing } \\
\cline { 2 - 4 } & Positive & Negative & Total \\
\hline Multibacillary & 19 & $03 *^{1}$ & 22 \\
Paucibacillari* & 08 & 23 & 31 \\
Contact** & 12 & 40 & 52 \\
No contact** & 0 & 25 & 25 \\
\hline Total & 39 & 91 & 130 \\
${ }^{1}$ Three were discharged from treatment. ${ }^{*} \mathrm{p}<0,0001 . * * \mathrm{p}<0,0227$ & &
\end{tabular}

In Brazil, despite actions for the treatment and control of leprosy, the number of new cases is highly threatening, and considering the existence of infected and undiagnosed people as a true reservoir of $M$. leprae and their contacts (Braber 2004) as infection sources, the development of methods for early diagnosis become imperative. PCR is a useful tool for the diagnosis of leprosy and its recent developments such as helicase dependent amplification point to the possibility of developing methods of detection with better sensitivity and specificity. (Bang et al. 2009) evaluated the sensitivity and utility of polymerase chain reaction (PCR) to detect $M$. leprae in comparison with other conventional methods for the diagnosis such as split skin smears, histopathology and serodiagnosis. They observed that the PCR detection of M. leprae targeting $16 \mathrm{~S}$ ribosomal RNA was specific and more sensitive than the conventional methods, and could contribute to early and accurate diagnosis of leprosy. The present work standardized a PCR technique to amplify the single copy gene Lsr2 of M. leprae. This technique presented $100 \%$ of specificity for $M$. leprae relative to other mycobacteria, in agreement with previous reports (Santos et al. 2001; Guerrero et al. 2002; Torres et al. 2003; Willams et al. 2003; Braber 2004; Cortes-Herrera et al. 2008). Therefore, it seemed possible to use this gene as a target for large-scale screening of human reservoirs of $M$. leprae, Despite the small number of patients with multibacillary leprosy, the majority of the inhabitants of endemic areas showed the signs of exposure to M. leprae, which could be explained by the presence of subclinical bacilliferous infections in the community. (Guerrero et al. 2002) studied the use of a polymerase chain reaction (PCR) test to detect LSR/A15 gene that coded for the $15 \mathrm{kDa} M$. leprae antigen in the samples of nasal mucus from asymptomatic household contacts of patients with leprosy. Their finding demonstrated that this method could be used to monitor the high-risk populations and also for the elimination programs in the countries where the disease's prevalence has been significantly reduced. Recent advances in the molecular epidemiology of leprosy through the genotyping of variable number tandem repeats (VNTRs) and single nucleotide polymorphisms (SNPs) have been described. VNTRs with a broad range of diversity are useful genotyping tools for analyzing the transmission in community areas, and SNPs and VNTRs with a small degree of variation are favorable for investigating the global transmission of leprosy (Matsuoka 2009). The use of PCR for the early diagnosis to detect $M$. leprae in leprosy patients as well asymptomatic household contacts 
of patients with leprosy with a high risk for developing or transmitting the disease would be of clinical and predictive value. While the prevalence of leprosy has declined around the world, there has not been a corresponding decrease in its incidence, thus indicating that it has not been possible to prevent the transmission of the disease.

\section{ACKNOWLEDGEMENT}

We thank Sociedade Filantrópica Humanitas for their colaboration, Dr. John Spencer and Dr. Patric Brennan for their inestimable attention, and also Dr. Halha Ostrensky Saridakis for samples supply.

\section{REFERENCES}

Bang PD, Suzuki K, Phuong le T, Chu TM, Ishii N, Khang TH, Evaluation of polymerase chain reactionbased detection of Mycobacterium leprae for the diagnosis of leprosy. J. Dermatol, 2009, 5: 269276.

Braber KL, Na Evaluation of GAEL, the Global Alliance for the Elimination of Leprosy. Leprosy Rev, 2004, 75:208-213.

Braga FJHN, Nuclear medicine in tropical diseases. Braz Arch Biol Technol, 2002, 45: 1-7.

Chae GT, Lee SB, Kang TJ, Shin HK, Kim JP, Ko YH, Kim SH, Kim NH, Typing of clinical isolates of Mycobacterium leprae and their distribution in Korea. Lepr Rev, 2002, 73: 41-46.

Cole ST, Eiglmeier K, Parkhill J, James K.D, Thomson NR, Wheeler PR, Honoré N, Garnier T, Churcher C, Harris D, Mungall K, Basham D, Brown D, Chillingworth T, Connor R, Davies RM, Devlin K, Duthoy S, Feltwell T, Fraser A, Hamlin N, Holroyd S, Hornsby T, Jagels K, Lacroix C, Maclean J, Moule S, Murphy L, Oliver K, Quail MA, Rajandream MA, Rutherford KM, Rutter S, Seeger K, Simon S, Simmonds M, Skelton J, Squares R, Squares S, Stevens K, Taylor K, Whitehead S, Woodward JR, Barrell BG, Massive gene decay in the leprosy bacillus. Nature, 2001, 409: 1007-1011.

Cortez-Herrera E, Sperhacke RD, Becker D, Kritski A, Zaha A, Rossetti MLR, Internal control in PCR for Mycobacterium tuberculosis: usefulness and improvement of the diagnosis. Braz Arch Biol Technol, 2008, 4: 685-691.

De Wit MYL, Faber WR, Krieg SR, Douglas JT, Lucas $\mathrm{SB}$, Montreewasuwar N, Application of a polymerase chain reaction for the detection of Mycobacterium leprae in skin tissues. J Clin Microbiol, 1991, 29: 906-910.

De Zubiria R, Rodriguez G, Historia de la lepra: ayer, hoy y mañana. Medicina (Bogotá), 2003, 61: 33-46.

Fernández JL, Rangel Mayoral JF, Rubio FJ, A review on hansen's disease. Farm Hosp, 2004, 2: 123-129.

Goulart IMB, Ferreira FR, Goulart LR, Pinheiro CA, Borges DS, Cunha G, Detection of Mycobacterium leprae by PCR in nasal and buccal mucosae in leprosy patients and household contacts. Int J Lepr other Mycobact Dis, 2001, 69: S230.

Guerrero MI, Arias MT, Garcés MT, León CI, Developing and using a PCR test to detect subclinical Mycobacterium leprae infection. Rev Panam Salud publica, 2002, 4: 228-34.

Hartskeerl RA, De Wit MYL, Klatser PR, Polymerase chain reaction for the detection of Mycobacterium leprae. J Gen Microbiol, 1989, 135: 2357-2364.

Jianping S, Wenzhong L, Meiwen Y, Jun Y, Longchao Z, Rongmao W, Lufang H, Hongjiang M, Fuchang Y, Xinguo $\mathrm{H}$ and Liangde $\mathrm{P}$, Analysis on the detection of new leprosy cases before, during and after the year of leprosy elimination campaings. Lepr Rev, 2004, 2: 157-163.

Marques MA, Espinosa BJ, Xavier da Silveira EK, Pessolani MC, Chapeaurouge A, Perales J, Dobos KM, Belisle JT, Spencer JS, Brennan PJ, Continued proteomic analysis of Mycobacterium leprae subcellular fractions. Proteomics, 2004, 10: 29422953.

Matsuoka M, Recent advances in the molecular epidemiology of leprosy. Nihon Hansenbyo Gakkai Zasshi, 2009, 1: 67-73.

Meima A, Smith WCS, Oortmarssen GJV, Richardus JH, Habbema JDF, The future incidence of leprosy: a scenario analysis. Bull World Health Organ, 2004, 5: 373-386

Misra N, Ramesh V, Misra RS, Narayan NP, Colston MJ, Nath I, Clinical utility of LSR/A15 gene for Mycobacterium leprae detection in leprosy tissues using the polymerase chain reaction. Int J Lepr other Mycobact Dis, 1995, 1: 35-41.

Nurse P, Systems biology: understanding cells. Nature, 2003, 424: 883.

Oftung F, Mustafa AS, Wiker HG, Extensive sequence homology between the Mycobacterium leprae LSR $(12 \mathrm{kDa})$ antigen and its Mycobacterium tuberculosis counterpart. FEMS Immunol Med Microbiol, 2000, 1: 87-89.

Sakamuri RM, Kimura M, Li W, Kim HC, Lee H, Balagon M, Gelber R, Cho SN, Brennan PJ, Vissa V, Population based molecular epidemiology of leprosy 
in Cebu, Philippines. J Clin Microbiol, 2009, 9: 28442854.

Santos AR, Balassiano V, Oliveira MLW, Pereira MAS, Santos PB, Degrave WM, Suffys PN, Detection of Mycobacterium leprae DNA by polimerase chain reaction in the blood of individuals, eight years after completion of anti-leprosy therapy. Mem Inst Oswaldo Cruz, 2001, 8: 1129-1133.

Santos AR, Filho JT, Nery JC, Duppre NC, Gallo ME, Suffys PN, Degrave WM, Goes evaluation of PCR mediated DNA amplification in noninvasive biological specimens for subclinical detection of Mycobacterium leprae. FEMS Immunol Med Microbiol, 1995, 11: 113-120.

Siddiqui MR, Meisner S, Tosh K, Balakrishnan K, Ghei S, Fisher SE, Golding M, Narayan NPS, Sitaraman T, Sengupta U, Pitchappan R, Hill AVS, A major susceptibility locus for leprosy in India maps to chromosome 10p13. Nature, 2001, 4: 439-441.

Torres P, Camarena JJ, Gomez JR, Nogueira JM, Gimeno V, Navarro JC, Olmos A, Comparison of PCR mediated amplification of DNA and the classical methods for detection of Mycobacterium leprae in different types of clinical samples in leprosy patients and contacts. Lepr Rev, 2003, 74: 18-30.

Vincent $\mathrm{M}, \mathrm{Xu} \mathrm{Y}$, Kong $\mathrm{H}$, Helicase-dependent isothermal DNA amplification. EMBO Reports, 2004; 5: 795-800.

Willams DL, Scollard DM, Gillis TP, PCR-based diagnosis of leprosy in the United States. Clin Microbiol Newsletter, 2003, 8: 57-61.
Wiwanitkit V, Analysis of Mycobacterium leprae genome: in silico searching for drug targets. Southeast Asian J Trop Med Public Health, 2005, 4: 225-227.

Woods SA, Coloe ST, A rapid method for the detection of potentially viable Mycobacterium leprae in human biopsies: a novel application of PCR. FEMS Microbiol Letter, 1989, 65: 305-310.

Yoon K, Cho S, Lee M, Hablaos RM, Cellona RV, Fajardo Jr TT, Evaluation of polymerase chain reaction amplification of Mycobacterium leprae: specific repetitive sequence in biopsy specimens from leprosy patients. J Clin Microbiol, 1993, 31: 895-899.

Young D, Leprosy and genome -not yet a burntout case. The Lancet, 2001, 357: 1639-1640.

Zanazzi NVG, Timpl R, Talts JF, Salzer JL, Brennan PB, Rambukkana A, Role of the cell wall phenolic lycolipid-1 in the peripheral nerve predilection of Mycobacterium leprae. Cell, 2000, 103: 511-524. 


\section{PÁGINA \\ EM \\ BRANCO}

